\title{
PENGARUH SUBSTITUSI IKAN TUNA (Thunnus $s p$ ) TERHADAP MUTU ORGANOLEPTIK DAN KIMIA ABON JANTUNG PISANG (Musa acuminate balbisiana colla)
}

\author{
Widia Dara, Antia Fanyalita \\ Program Studi Gizi Sekolah Tinggi Ilmu Kesehatan Perintis Padang \\ Jalan Adinegoro KM 17 Simpang Kalumpang Padang \\ Email: widianurja@gmail.com
}

\begin{abstract}
The purpose of this research is to know the making of shredded banana flower that has been boild and fried (abon) with an experiment of tuna substitution of $0 \%, 25 \%, 50 \%$ and $75 \%$ from weight of banana flower. The highest yield of $42 \%$ was obtained from the making of abon consisting of $25 \%$ banana flower and $75 \%$ tuna. The best result of organoleptic test result is D treatment (comparison of banana flower and tuna were 25\%: 75\%) in the likes category. Protein content increases with the increasing number of substitutes of tuna, otherwise the fiber content decreases. Fat content was between $18-20 \%$. The most preferred abon chemical content (abon D) in every $100 \mathrm{~g}$ of abon contains 302 calories, $20.6 \%$ carbohydrate, $14.0 \%$ protein, $18.2 \%$ fat, ash content $4.2 \%$ and water content $42.9 \%$ and fiber $0.92 \mathrm{~g}$. Abon D is made from $25 \%$ banana heart and $75 \%$ tuna meets SNI abon fish standard, except for the water content is still a bit high that is more than $10 \%$ of SNI standards.
\end{abstract}

Key words: Abon, tuna, banana heart, chemical quality, organoleptic

\section{PENDAHULUAN}

\section{Latar Belakang}

Jantung pisang mengandung zat gizi yang bermanfaat bagi tubuh, dalam setiap 100 gram bobot jantung pisang mengandung : protein $1,6 \%$, karbohidrat $9,9 \%$, serat $5,7 \%$, mineral $1,2 \%$ dan lemak total $0,6 \%$. Jantung pisang juga mengandung mineral (terutama fosfor, kalsium, dan besi), serta sejumlah vitamin A, B1 dan C (Astawan, 2008).

Salah satu pemanfaatan jantung pisang dalam pengolahan dapat dijadikan abon. Abon yang berbahan baku jantung pisang ini diolah menjadi produk yang memiliki banyak manfaat untuk kesehatan. Karena jantung pisang itu sendiri memiliki jumlah serat yang cukup tinggi. Namun abon jantung pisang memiliki protein yang rendah. Rendahnya protein dalam abon jantung pisang perlu dilakukan penambahan dengan pangan sumber protein.

Sumber protein hewani dapat dipenuhi dengan mengkonsumsi ikan. Ikan merupakan sumber pangan yang relatif ekonomis jika dibandingkan dengan sumber protein hewani lainnya. Ikan sebagai bahan makanan telah diidentifikasi sebagai pangan yang memiliki keunggulan tertentu. Keunggulan utama produk ikan adalah nilai cerna protein ikan sangat tinggi (lebih dari 90\%) sehingga ikan mudah untuk dicerna karena daging ikan lebih lembut dibandingkan dengan hewani lainnya. Selain kaya akan protein yang bermutu tinggi, vitamin yang banyak tedapat pada ikan adalah vitamin yang larut lemak (vitamin A dan D). Ikan mengandung asam lemak tak jenuh. Dibandingkan dengan lemak hewani lainnya, lemak ikan sangat sedikit mengandung kolesterol. 
Ikan tuna merupakan salah satu jenis ikan laut yang cukup potensial di-Sumatera. Tuna merupakan ikan laut yang memiliki daging tebal dengan rasa yang enak dan memiliki kandungan omega-3 lebih banyak dibanding ikan air tawar, yaitu mencapai 28 kali. Konsumsi ikan tuna $30 \mathrm{~g}$ sehari dapat mereduksi risiko penyakit jantung hingga $50 \%$ (Kordi, 2010). Tingginya nilai ekonomis ikan tuna memacu sektor perindustrian pengolahan tuna untuk tujuan ekspor di Sumatera Barat.

Adawiyah (2008) juga mengemukakan bahwa ikan selain kandungan proteinnya sangat tinggi juga mempunyai nilai biologis yang sangat tinggi yaitu $80 \%$ jaringan pengikatnya sedikit, umumnya berdaging tebal dan putih sehingga memungkinkan untuk dijadikan berbagai macam olahan. Salah satu jenis ikan yang baik untuk dijadikan bahan tambahan abon jantung pisang adalah ikan tuna. Dengan pembuatan abon jantung pisang yang di substitusi ikan tuna diharapkan dapat menghasilkan abon yang bermutu tinggi dan meningkatkan daya terima masyarakat terhadap abon jantung pisang. Berdasarkan uraian ini dilakukan penelitian tentang pengaruh substitusi ikan tuna (Thunnus sp) terhadap mutu kimia dan mutu organoleptik abon jantung pisang (Musa cuminata balbisiana colla.)"

Tujuan penelitian adalah untuk mengetahui pengaruh substitusi ikan tuna terhadap mutu organoleptik dan kandungan kimia abon jantung pisang.

\section{METODE PENELITIAN}

Penelitian ini dilakukan pada bulan MeiAgustus 2016. Analisis kandungan kimia dilakukan di Laboratorium Teknologi Hasil Pertanian Universitas Andalas. Uji organoleptik dilakukan di kampus STIKes Perintis Padang. Penelitian ini merupakan penelitian eksperimen, dengan substitusi ikan tuna dengan jumlah yang berbeda dalam pembuatan abon jantung pisang yaitu : A (100\% jantung pisang : $0 \%$ ikan tuna) sebagai kontrol, B (75\% jantung pisang: $25 \%$ ikan tuna), C (50\% jantung pisang:50\% ikan tuna) dan $\mathrm{D}$ (25\% jantung pisang:75\% ikan tuna). Bahan lain yang ditambahkan dalam pembuatan abon adalah santan. Rempahrempah yang digunakan yaitu ketumbar, bawang merah, laos, jahe, sereh satu tangkai, bawang putih, daun salam, daun jeruk, gula merah dan garam. Minyak goreng untuk menumis yang digunakan minyak kelapa.

Bahan untuk analisis kandungan kimia : aquades, $\mathrm{H} 2 \mathrm{SO} 4, \mathrm{NaOH}, \mathrm{N}$-heksan, indikator metil merah, indikator metil biru asam oksalat, $\mathrm{CuSO} 4$, etanol dan $\mathrm{HCl}$. Uji organoleptik dilakukan untuk mengetahui tingkat kesukaan panelis terhadap abon yang dibuat. Metode yang digunakan adalah uji hedonic yang meliputi warna, aroma dan tekstur dan rasa abon. Pengujian organoleptik dilakukan untuk mengetahui preferensi panelis sebanyak 30 orang dengan skala hedonik satu sampai enam dengan kriteria (1) sangat tidak suka, (2) tidak suka, (3) biasa saja, (4) suka, (5) sangat suka dan (6) amat sangat suka

Untuk melihat pengaruh perlakuan substitusi ikan tuna terhadap mutu organoleptik dilakukan analisis ANOVA pada taraf $5 \%$. Bila $\mathrm{F}$ hitung $>\mathrm{F}$ tabel berarti ada perbedaan antara perlakuan. Jika berbeda antara perlakuan dilanjutkan dengan uji Wilayah berganda Duncan (DNMRT), (Setyaningsih dkk, 2010). Analisis data dengan menggunakan bantuan sofware mikrosotft exel.

Analisis kandungan kimia dengan penghitungan kadar air metode pengeringan dengan oven, kadar abu dengan tanur (Sudarmadji, et al 1997). Kadar protein ditentukan dengan cara kjeldahl (Apriyantono., et al ,1989). Analisis kadar lemak menggunakan metode ekstraksi soxhlet menurut Sudarmadji, et al (1997) serta pengujian kadar serat (Sudarmadji, 2003).

\section{HASIL DAN PEMBAHASAN}

\section{Mutu Rendemen}

Rendemen adalah persentase rasio antara produk terhadap bahan baku awal yang dgunakan. Hasil rendemen tertinggi didapatkan dari pembuatan abon yang terdiri dari $25 \%$ jantung pisang dan $75 \%$ ikan tuna. Menurut 
Dara, W., \& Fanyalita, A. 2017. Pengaruh Subtansi Ikan Tuna ((thunnus sp) terhadap mutu organoleptik dan kimia abon jantung pisang (musa acuminate balbisiana colla). Journal of Sainstek 9(1): 1-7

Rahmat (2002) rendemen pada pembuatan abon dipengaruhi oleh penyusutan kadar air bahan saat pengovenan. Selain itu rendemen juga dipengaruhi oleh penyusutan kadar air pada saat pemasakan awal, ikan yang terbuang pada saat pencabikan, pengepresan daging, penambahan bumbu pada saat pengolahan dan penyusutan saat penggorengan.

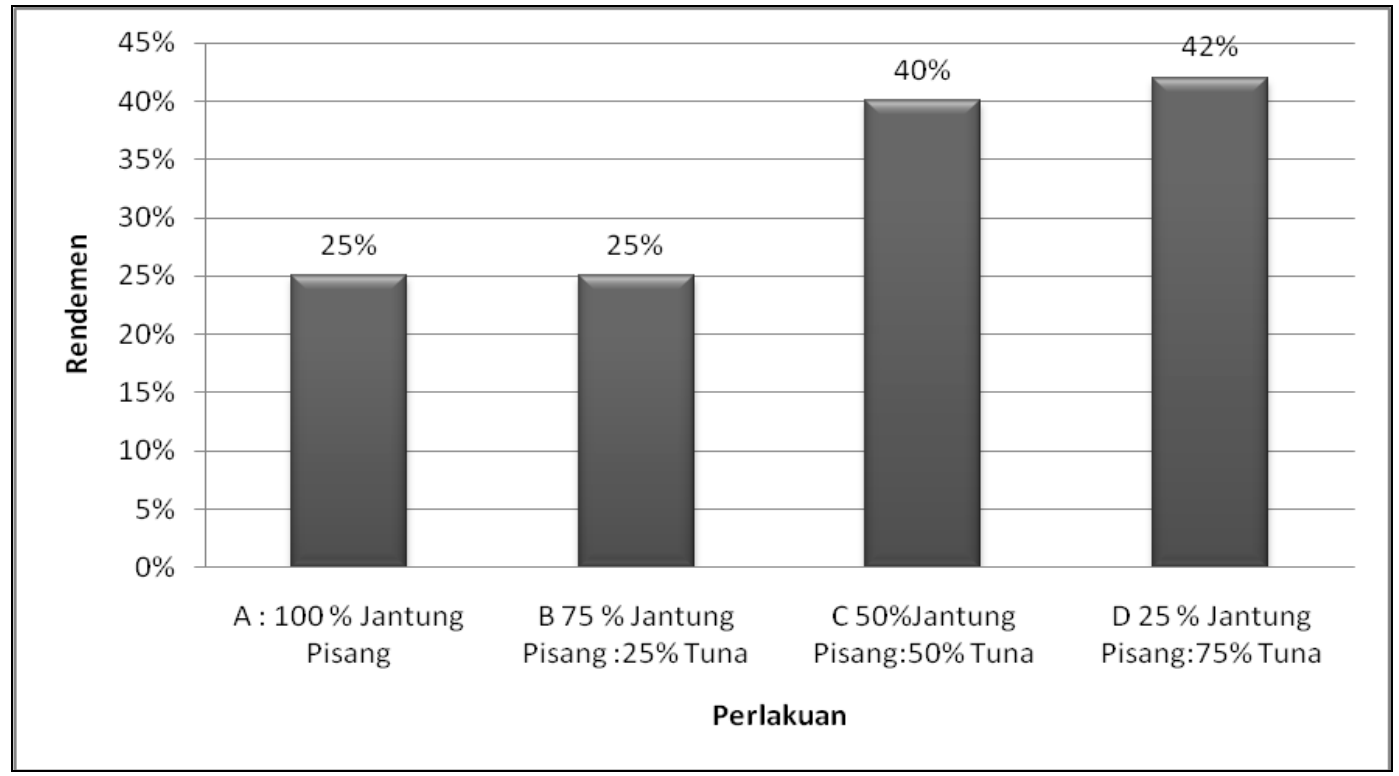

Gambar 1. Grafik Rendemen abon jantung pisang

Dari grafik diatas rendemen abon yang tertinggi adalah abon dengan substitusi ikan tuna $75 \%$ sebesar $42 \%$ dan yang terkecil adalah abon tanpa substitusi ikan tuna $25 \%$ dan abon jantung pisang saja, yaitu sebesar $25 \%$.

\section{Uji Organoleptik}

Penilaian uji organoleptik terhadap abon jantung pisang dengan substitusi ikan tuna yang berbeda dilakukan oleh 30 panelis agak terlatih meliputi indikator warna, aroma, tekstur, rasa dilihat pada gambar 2 . 


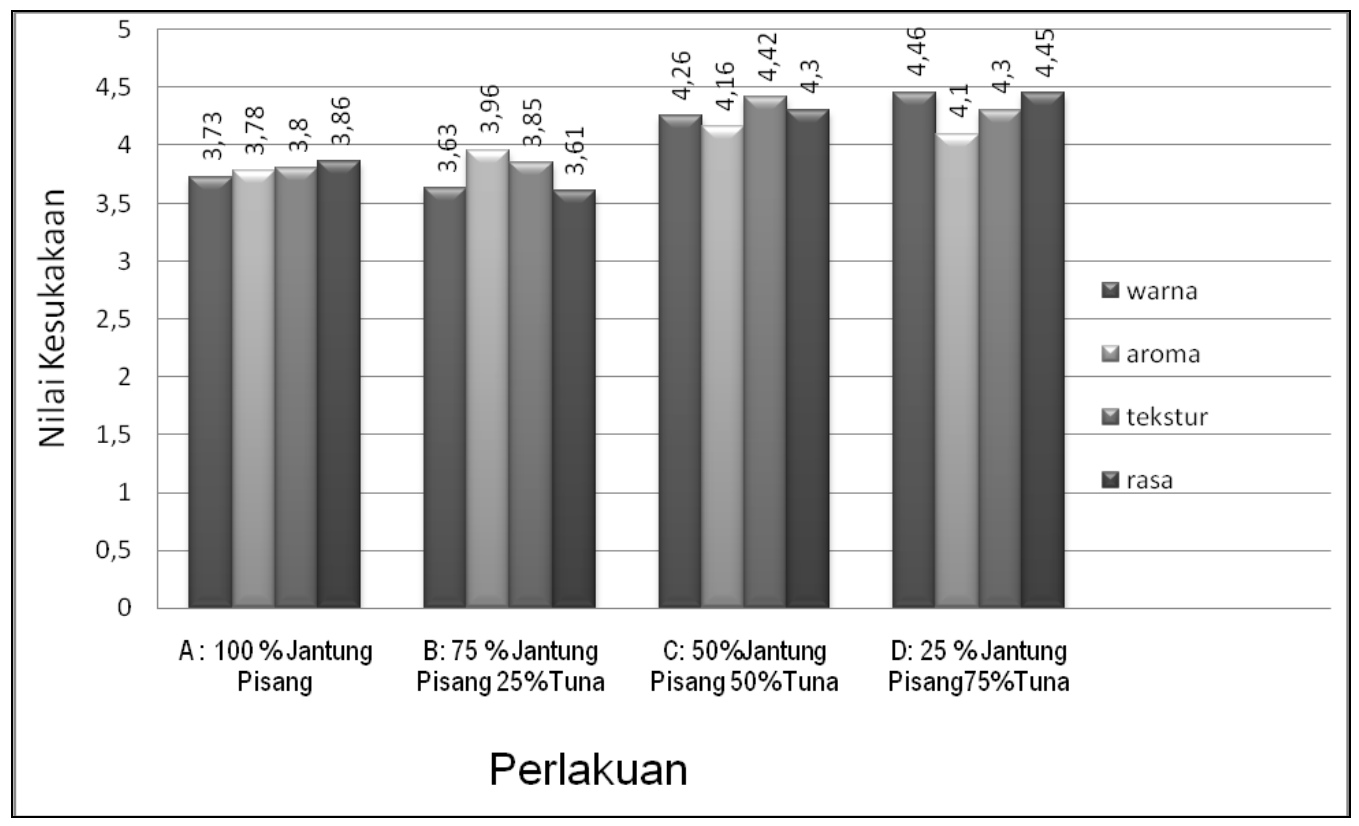

Gambar 2. Nilai Uji Organoleptik Abon Jantung Pisang yang disubstitusi Ikan Tuna

\section{Mutu Warna}

Warna merupakan indikator yang dapat langsung dilihat oleh indera penglihatan. Sehingga warna menjadi indikator pertama yang langsung dilihat atau diamati oleh panelis.

Nilai rata - rata kesukaan terhadap warna abon yang di berikan panelis berkisar antara $3.63-4,46$. Warna yang paling di sukai panelis adalah abon yang dibuat dengan perlakuan D (25\% jantung pisang : $75 \%$ ikan tuna) dengan warna coklat keemasan. Berdasarkan analisis Anova ternyata ada perbedaan warna yang nyata antar perlakuan. Hasil uji lanjut wilayah berganda duncan pada taraf uji 5\% di dapatkan perlakuan A berbeda nyata dengan perlakuan B,C,D. Warna abon yang paling disukai panelis adalah perlakuan $\mathrm{D}$ (25: 75) dengan nilai 4.46 pada kategori suka. Warna abon perlakuan D adalah adalah warna coklat keemasan. dan menjadi kriteria yang paling disukai panelis. Warna abon pada perlakuan A dan B yaitu coklat gelap yang disebabkan karena banyaknya konsentrasi jantung pisang pada abon sedangkan warna perlakuan $\mathrm{C}$ dan $\mathrm{D}$ yaitu coklat keemasan.
Konsentrasi jantung pisang yang lebih banyak pada abon menyebabkan abon lebih cepat gosong yang menyebabkan warna abon menjadi lebih gelap. Perbedaan warna pada saat penggorengan bisa disebabkan oleh perbedaan panas yang masuk ke bahan. Menurut Ketaren (2008), intensitas warna tergantung dari lama, suhu dan komposisi kimia permukaan bahan.

\section{Mutu Aroma}

Indikator kedua yaitu aroma. Aroma makanan banyak menentukan kelezatan makanan tersebut, oleh karena itu aroma merupakan salah satu faktor dalam penentuan mutu. Aroma yang khas dan menarik dapat membuat makanan lebih disukai oleh konsumen sehingga perlu diperhatikan dalam pengolahan suatu bahan makanan.

Dari hasil penilaian panelis aroma terbaik dari abon adalah pada perlakuan C $(50 \%$ jantung pisang, 50\% ikan tuna), yaitu 4,16 ( suka). Dari hasil analisis sidik ragam didapatkan bahwa perbandingan jantung pisang dan ikan tidak memberikan pengaruh nyata terhadap bau/aroma abon. Menurut Aida, dkk (2014) pada pembuatan abon jantung pisang 
Dara, W., \& Fanyalita, A. 2017. Pengaruh Subtansi Ikan Tuna ((thunnus sp) terhadap mutu organoleptik dan kimia abon jantung pisang (musa acuminate balbisiana colla). Journal of Sainstek 9(1): 1-7

dengan penambahan ikan layang, aroma yang dihasilkan hanya sedikit memiliki bau khas ikan, aroma dominan berasal dari bumbubumbu yang digunakan yang terdiri dari bawang putih dan bawang merah, sereh dan jahe selain itu juga dapat berasal dari santan yang menyebabkan aroma gurih. Begitu juga aroma pada abon ini, lebih kuat aroma bumbu daripada aroma ikan dan jantung pisangnya.

\section{Mutu Tekstur}

Tekstur merupakan kenampakan luar suatu produk yang dapat dilihat secara langsung. Tekstur pada produk makanan dan minuman akan mempengaruhi penilaian tentang diterima atau tidaknya produk tersebut. Dalam penelitian ini tekstur yang dinilai adalah kelembutan abon. Nilai rata-rata kesukaan terhadap tekstur abon yang di berikan panelis berkisar $3.8-4,3$ dari data tersebut rata-rata panelis menilai antara biasa sampai suka. Hasil uji Anova di dapatkan perbedaan yang nyata antar perlakuan. Hasil uji lanjut dengan analisis wilayah berganda Duncan didapatkan bahwa perlakuan abon yang dibuat dari 100\% jantung pisang berbeda nyata dengan perlakuan abon lainnya. Tekstur abon yang paling disukai panelis adalah perlakuan D (25\% jantung pisang dan $75 \%$ ikan tuna) dengan nilai 4.3 (suka).

Tekstur merupakan salah satu kriteria yang sangat penting pada suatu produk karena sangat mempengaruhi citra makanan. Tekstur yang umum pada produk abon adalah kerenyahan dan sensasi gurih di dalam mulut. Tekstur yang baik dapat menambah tingkat kesukaan konsumen terhadap suatu produk. Tekstur dari semua kombinasi perlakuan sulit dibedakan oleh panelis karena tekstur dari jantung pisang dan ikan tuna memiliki karakter yang hampir sama.

\section{Mutu Rasa}

Pada umumnya bahan pangan tidak hanya terdiri dari satu rasa, tetapi merupakan gabungan berbagai macam rasa secara terpadu sehingga menimbulkan cita rasa yang utuh. Tingkat kesukaan abon yang di berikan panelis berkisar 3,61 - 4.45 dari data tersebut rata-rata panelis memberikan penilai pada kategori biasa sampai suka. Hasil uji hedonik maka di dapatkan perbedaan yang nyata antar perlakuan. Hasil uji lanjut wilayah bergandan Duncan pada taraf $5 \%$, didapat bahwa perlakuan A berbeda nyata dengan perlakuan B,C,D. Perlakuan yang memiliki tingkat kesukaan rasa tertinggi adalah perlakuan D yaitu $25 \%$ jantung pisang dan $75 \%$ ikan tuna dengan nilai 4.45. Cita rasa makanan merupakan salah satu faktor penentu bahan makanan. Makanan yang memiliki rasa yang enak dan menarik akan disukai oleh konsumen. (Winarno, 2004). Hal ini disebabkan karena komposisi jantung pisang sedikit dibandingkan kosentrasi ikan sehingga tidak munculnya rasa jantung pisang yang dominan dibanding perlakuan A, B dan C

Berdasarkan hasil analisis mutu hedonik bahwa perlakuan D (25\% jantung pisang dan $75 \%$ ikan tuna) memiliki rata - rata kesukaan terhadap uji organoleptik lebih tinggi di banding perlakuan A (100:0), B (75:25), dan perlakuan $C(50$ : 50$)$. Hal ini menunjukan bahwa pembuatan Abon dengan substitusi ikan tuna perlakuan D lebih di sukai oleh panelis, dimana warna, tekstur dan rasa lebih di sukai panelis. Sedangkan dari segi aroma yang lebih disukai panelis adalah perlakuan C ( 50:50). Hasil penelitian Hardoko (2015) pada pembuatan abon dari pindang ikan tongkol yang disubstitusi jantung pisang hasil terbaik didapatkan pada substitusi $50 \%$ jantung pisang (b/b).

\section{Mutu Kimia}

Berdasarkan analisis kandungan kimia dapat dilihat hasil kandungan gizi yang terdapat dalam abon pada table 1 dibawah ini.

Tabel 1. Hasil Analisis Kandungan kimia Abon Jantung Pisang yang Disubstitusi Ikan Tuna 
Dara, W., \& Fanyalita, A. 2017. Pengaruh Subtansi Ikan Tuna ((thunnus sp) terhadap mutu organoleptik dan kimia abon jantung pisang (musa acuminate balbisiana colla). Journal of Sainstek 9(1): 1-7

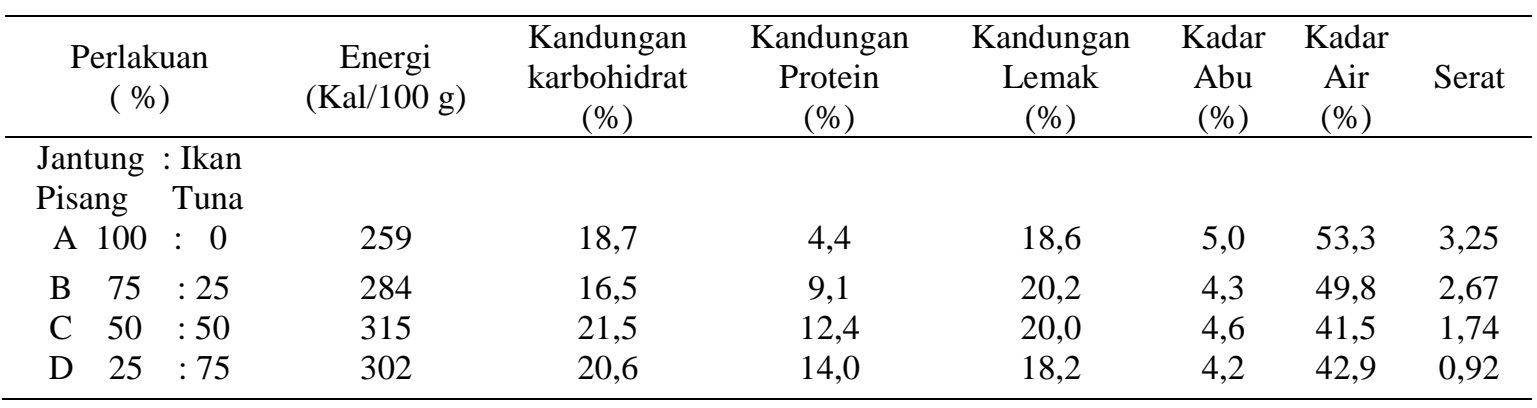

Berdasarkan analisis proksimat kandungan gizi dapat dilihat hasil kadar protein abon jantung pisang dengan substitusi ikan tuna (100:0), (75:25) ), (50:50), (25:75) terjadi peningkatan pada kandungan proteinnya, yaitu secara berturut-turut sebesar $4,4 \%, 9,1 \% 12,4$ $\%$, dan $4,0 \%$.

Hasil tertinggi kandungan protein abon jantung pisang dengan substitusi ikan tuna pada perlakuan D (25: 75). Hal ini dapat terjadi karena perbandingan persentase ikan tuna lebih besar dibandingkan dengan jantung pisang. Ikan tuna memiliki kadar protein tinggi yaitu sebesar $28.3 \%$ (info fish), sedangkan jantung pisang memiliki kadar protein sebesar $1.6 \%$ Astawan, (2008). Dengan demikian kadar protein pada ikan tuna dan jantung pisang akan berpengaruh terhadap kandungan protein abon yang dihasilkan. Abon yang dibuat pada semua perlakuan sudah memenuhi SNI abon No 036880, 0368-85, dimana pada standar SNI kandungan protein abon maksium $20 \%$.

Kandungan lemak abon berkisar antara 18,2-20,2 \%. Kandungan lemak abon pada keempat contoh abon yang dibuat sudah memenuhi standar SNI abon yaitu maksimum $30 \%$. Kandungan air abon masih tinggi yaitu berada pada kisaran 41,5 sampai 53,3\%. Kadar air ini masih tinggi. Sementara kadar air abon sesuai standar yang dibuat SNI hanya dibolehkan maksimum $10 \%$. Kadar air yang tinggi dapat disebabkan oleh jantung pisang yang memang mengandung kadar air yang tinggi. Kadar air dapat mempengaruhi keawetan dan masa simpan makanan. Untuk mengurangi kadar air pada makanan dapat dilakukan dengan mempres abon setelah penggorengan.

Berdasarkan pada Tabel 1 kadar serat yang terdapat pada abon jantung pisang dengan substitusi ikan tuna mengalami penurunan, semakin bertambah substitusi ikan tuna kadar serat abon semakin berkurang. Kadar abu abon semakin berkurang dengan bertambahnya substitusi ikan tuna. Yaitu dari kadar 5,0 \% menurun sampai 4,2 \%. Kadar abu sudah memenuhi standar SNI abon yaitu maksimum kadar abu yang dibolehkan adalah sebesar 9\%.

\section{KESIMPULAN}

Abon yang paling disukai dari segi cita rasa adalah perlakuan D yang dibuat dari $25 \%$ jantung pisang dan $75 \%$ ikan tuna. Kandungan protein meningkat seiring dengan semakin banyaknya substitusi ikan tuna, sebaliknya kandungan seratnya bertambah. Kandungan kandungan kimia abon D adalah 302 Kalori, $20,6 \%$ karbohidrat, $14,0 \%$ protein, $18,2 \%$ lemak, kadar abu 4,2 \% dan kadar air 42,9\% serta serat $0,92 \mathrm{~g}$. Abon yang dibuat dari $25 \%$ jantung pisang dan $75 \%$ ikan tuna memenuhi standar SNI abon. Kecuali untuk kandungan air yang masih agak tinggi yaitu lebih dari $10 \%$ standar SNI.

Diharapkan kepada masyarakat agar mampu memanfaatkan limbah jantung pisang ini sebagai makanan untuk pengganti lauk pauk, dengan perbandingan substitusi ikan tuna ( 25 : 75 ) di samping itu abon jantung pisang yang disubstitusi ikan tuna juga meningkatkan kandungan protein. 
Dara, W., \& Fanyalita, A. 2017. Pengaruh Subtansi Ikan Tuna ((thunnus sp) terhadap mutu organoleptik dan kimia abon jantung pisang (musa acuminate balbisiana colla). Journal of Sainstek 9(1): 1-7

\section{DAFTAR KEPUSTAKAAN}

Adawiyah R. 2008. Pengolahan dan Pengawetan Ikan. Jakarta: PT. Bumi Aksara.

Aida Y. dkk. 2014. Pemanfaatan jantung pisang (Musa paradisiaca) dengan penambahan daging ikan layang (decapterus sp.) pada pembuatan abon. J. Ilmu dan Teknologi Pangan, Vol. 2 No. 1 Th. 2014. Politeknik Gorontalo.

Hardoko, dkk. 2015. Substitusi Jantung Pisang dalam Pembuatan Abon dari Pindang Ikan Tongkol. Jurnal Perikanan dan Kelautan 20.1.juni 2015/01/01-10. ISSN 0853-7607
Ketaren S. 2008. Minyak dan Lemak Pangan. Jakarta: UI. Press.

Kordi M. 2010. Budidaya Biota Akuatik untuk Pangan, Kosmetik dan Obat-obatan. Yogyakarta: Lily publisher.

Mahmud, dkk. 2008. Tabel Komposisi Pangan Indonesia. Jakarta: PT Elex Media Komputindo.

Setyaningsih D, dkk. 2010. Analisis Sensori untuk Industri Pangan dan Agro. IPB Press. Bogor.

SNI 01-3707-1995. Abon. http://sisni.bsn.go.id/indekx.php/sns/4128 . SNI abon No 0368-80, 0368-85

Sudarmaji S, dkk. 2003. Analisis Bahan Makanan dan Pertanian. Yogyakarta: Penerbit Liberty. 